\title{
HERBAL MEDICINAL PLANTS ACTIVE AGAINST COVID-19 USED BY TRIBAL COMMUNITIES FROM NANDED DISTRICT (MS), INDIA
}

\author{
SACHIN S. SHINDE ${ }^{1^{*}}$ iD SHRIMANT D. RAUT $^{2}$, BHAGAWAT D. GACHANDE ${ }^{3}$ \\ 1,2,3 Department of Botany, Pratibha Niketan College, Nanded (MS), India \\ Email: ssshinde493@gmail.com
}

Received: 07 Dec 2021, Revised and Accepted: 01 Feb 2022

\begin{abstract}
Objective: Presently, the whole world is under threat and suffering from the disease COVID-19. WHO accepted that COVID-19 viral disease poses a serious health problem for the world and declared it as a pandemic. According to WHO Coronavirus (COVID-19), there have been 183,934,913 confirmed cases, including 3,985,022 deaths globally as of 6 July 2021. From India COVID-19 464357 active cases and 403281 deaths are being reported by $\mathrm{MOH}$ and FW, GOI as of 06 July 2021. The present scenario of the COVID-19 pandemic appears to provide no effective antiviral drug or vaccine therapy against this extremely contagious lethal infection. The COVID-19 mortality rate is found to be very high in people with weak immunity. India is a hub for herbals and that is the reason why the possibility to find a solution against COVID-19 is practically attainable.
\end{abstract}

Methods: The present study emphasizes various herbal plants potentially considered as part of formulation or used in the management of COVID19. Present data is collected from hilly tribal communities (Total= 180 respondents from which males are 112 and females 68 ) via., semi-structured questionnaires.

Results: A total of 17 traditional herbal medicinal plant species belonging to 13 different families are being used extensively for the improved immune system of the human body to fight against COVID-19 by tribal communities in the studied area.

Conclusion: This article will help researchers and industries to identify potential herbals for the treatment of COVID-19 viral infection.

Keywords: COVID-19, WHO, MOH and FW, GOI, Herbals

(C) 2022 The Authors. Published by Innovare Academic Sciences Pvt Ltd. This is an open access article under the CC BY license (https://creativecommons.org/licenses/by/4.0/) DOI: https://dx.doi.org/10.22159/ijpps.2022v14i3.43791. Journal homepage: https://innovareacademics.in/journals/index.php/ijpps.

\section{INTRODUCTION}

The Whole World is at present facing the biggest threat to humanity because of the COVID-19 pandemic. The common symptoms include cold, cough, fever, and difficulty in breathing. This disease spreads through the salivary droplets or sneezing or coughing fluid through an infected person. The two ways in which this virus spreads are, direct physical contact and indirect contact with the surface on which the infected droplets fall [1]. The COVID-19 has affected $183,934,913$ confirmed cases, including 3,985,022 deaths worldwide as of 6 July 2021 [2]. According to the MOH and FW, GOI-COVID-19, there are 464357 active cases and 403281 deaths as of 06 July 2021 [3]. Moreover, persons with weak immunity are easily susceptible to COVID-19 viral infection [4].

The current pandemic has created a huge burden on scientists and researchers to revisit the potential efficacy of herbal medicinal plants by identifying potential phytochemicals and their derivatives in treating COVID-19. Traditional herbal medicines are already in use for treating different viral infections [5]. Nearly $80 \%$ of the people are dependent on traditional plants for their primary health (according to a WHO report). Our traditional or ethnobotanical knowledge could help us find an alternative approach to search for possible antiviral drug molecules. The traditional Indian system of medicines (Ayurveda) has described the use of plants, which have several phytoconstituents that are useful for drug formulations. This system of medicine believes in using certain herbs, decoctions, and plant-based formulations helpful to build immunity. The research article aims to highlight the importance of plant-based natural products, herbs, and their derivatives that shows potential antiviral activity for COVID-19 viral inhibition.

\section{MATERIALS AND METHODS}

The study was conducted in different villages located in the Nanded District of Maharashtra state, India. The current study focuses on herbal medicinal plants from selected rural villages (Therban,
Somthana, Somthana-tanda, Shingarwadi, Dhawari, Dhanora, and Borgaon) situated in the Nanded District of Maharashtra. A detailed survey was undertaken from Jun 2020 to Jun 2021 to collect information on different herbs which are used for the prevention of COVID-19 by traditional healers from the Nanded district by following all COVID-19 safety measurements. Present information is acquired by tribal communities by questionnaires and oral interviews. During the survey, a Semi-structured questionnaire was used to interview respondents after Prior Informed Consent was obtained verbally with them before commencing each interview. A total of 180 informants (112 males and 68 females) between the ages group 20-90 y were interviewed. During the interviews, respondents were asked questions about the local names of plants, edible parts, the season of availability, methods of consumption, and medicinal uses. Among the 180 respondents interviewed in this study, most of them were elders aged above $60(n=93)$ followed by adults aged between 36-59 $(n=54)$. Youth aged between 20-35 ( $\mathrm{n}=$ 33) constituted the least category. The results show that elders contributed more information with medicinal values as compared to other age categories.

Regular field visits were done for collecting information and identification of plants the occurrence of herbals. During the field visits, the GPS Map Camera (Android Mobile app) was used to know the correct GPS latitude and longitude of herbal medicinal plants.

The frequency index was calculated according to [6].

The formula is $\mathrm{FI}=(\mathrm{FC} \div \mathrm{N}) \times 100$

Where, $\mathrm{FI}=$ Frequency index, $\mathrm{FC}=$ Number of participants and $\mathrm{N}=$ Total number of participants.

\section{RESULTS AND DISCUSSION}

The present study showed that the tribal healers use several traditional herbal medicinal plants practices for curing COVID-19 symptoms like cough, cold, sneezing and fever by using plant parts 
like leaves $(\mathrm{n}=03)$, fruits $(\mathrm{n}=04)$, seeds $(\mathrm{n}=01)$, underground parts\{roots/rhizome/bulb $\quad(\mathrm{n}=06)$, whole plants $(\mathrm{n}=01)$, flowers/floral parts $(\mathrm{n}=01)$, and stem $(\mathrm{n}=01)$ respectively as shows in (fig. 1).

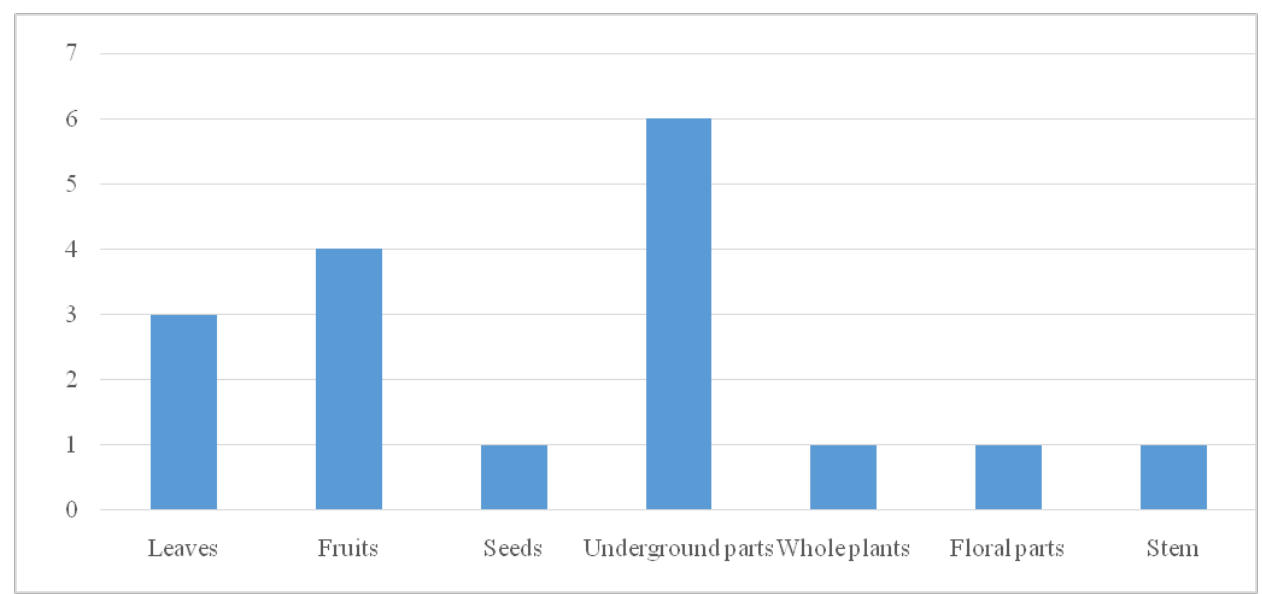

Fig. 1: Plant parts used by traditional healers for remedy preparations

A total of 17 traditional herbal medicinal plant species (i.e., Curcuma longa, Allium cepa, Zingiber officinale, Withania somnifera, Azadirachta indica, Tinospora cordifolia, Emblica officinale, etc.) of which (i.e.,07 Herbs, 05 Shrubs, 02 Trees, and 03 Climbers) belonging to 13 different families are being used extensively for curing COVID-19 by tribal communities in the studied area. Azadirachta indica leaves extract is useful for normal and malarial fever. It is highly recommended for the treatment of patients suffering from COVID-19 [11]. Aloe vera leaves sap is used for making juice and used for drinking purposes to enhance immunity both separately and in combination with other plant species. Fresh leaves of Ocimum sanctum are boiled in water and the decoction obtained is used in cough and cold. The fruits of Momordica charantia, Emblica officinalis, and Piper betel with honey are effective against cough [23]. Rhizome of Curcuma longa Linn. and Zingiber officinale Roscoe are beneficial against the human respiratory syncytial virus, thus preventing the infection [7]. Roots of Withania somnifera Linn. and Astragalus membranaceus have been used in various Indian ayurvedic medicines to enhance the immune system and fight against diseases (table 1). Stem and fresh leaves of Tinospora cordifolia A. Rich. are crushed and boiled in water and decoction is obtained to cure a cold and cough. Gravy is prepared by seed powder of Trigonella foenum-graecum Linn. by adding sugar with water and eaten during the winter season for self-immune enhancement. Bulb of Allium cepa Linn. and Allium sativum Linn. are the most important spices as well as the main ingredient in many traditional and folk medicines.

Table 1: Traditional herbal medicinal plants active against COVID-19 used by tribal communities from Nanded District (MS), India

\begin{tabular}{|c|c|c|c|c|c|c|c|c|c|}
\hline $\begin{array}{l}\text { S. } \\
\text { No. }\end{array}$ & $\begin{array}{l}\text { Scientific name of } \\
\text { plants, family, } \\
\text { and local name }\end{array}$ & $\begin{array}{l}\text { GPS } \\
\text { location }\end{array}$ & Habit & $\begin{array}{l}\text { Edible } \\
\text { part } \\
\text { used } \\
\end{array}$ & $\begin{array}{l}\text { Season of } \\
\text { availability }\end{array}$ & $\begin{array}{l}\text { Commerci } \\
\text { ally sold }\end{array}$ & $\begin{array}{l}\text { Frequency } \\
\text { index }\end{array}$ & $\begin{array}{l}\text { Method of } \\
\text { consumption }\end{array}$ & Medicinal properties \\
\hline 1. & $\begin{array}{l}\text { Curcuma longa } \\
\text { Linn. } \\
\text { (Zingiberaceae) } \\
\text { Haladi }\end{array}$ & $\begin{array}{l}\text { Latitude- } \\
19 * 16 ' 29 " \mathrm{~N} \\
\text { Longitude- } \\
77^{*} 41 \text { '17"E }\end{array}$ & Herb & Rhizome & $\begin{array}{l}\text { Throughout } \\
\text { year }\end{array}$ & Yes & 53 & $\begin{array}{l}\text { Native to India, used } \\
\text { in food preparation } \\
\text { as a spice and a } \\
\text { colouring agent. }\end{array}$ & $\begin{array}{l}\text { It is active against the } \\
\text { human respiratory } \\
\text { syncytial virus, thus } \\
\text { preventing the infection [7]. }\end{array}$ \\
\hline 2. & $\begin{array}{l}\text { Trigonella foenum- } \\
\text { graecum Linn. } \\
\text { (Fabaceae) Methi }\end{array}$ & $\begin{array}{l}\text { Latitude- } \\
19 * 16 ' 18 " \mathrm{~N} \\
\text { Longitude- } \\
77^{*} 41^{\prime} 47 " \mathrm{E}\end{array}$ & Herb & Seeds & $\begin{array}{l}\text { Throughout } \\
\text { year }\end{array}$ & Yes & 45 & $\begin{array}{l}\text { Gravy is prepared } \\
\text { with seed powder } \\
\text { and sugar mixed } \\
\text { with milk/water } \\
\text { and eaten during } \\
\text { the winter season } \\
\text { for self-immune } \\
\text { enhancement }\end{array}$ & $\begin{array}{l}\text { It helps in controlling } \\
\text { various enzymatic } \\
\text { activities, fever, body pain. } \\
\text { So, it is considered as one } \\
\text { of the remedies to relieve } \\
\text { some symptoms of SARS- } \\
\text { CoV viruses [8]. }\end{array}$ \\
\hline 3. & $\begin{array}{l}\text { Zingiber officinale } \\
\text { Roscoe } \\
\text { (Zingiberaceae) } \\
\text { Adrak }\end{array}$ & $\begin{array}{l}\text { Latitude- } \\
19 * 16 ' 15 " \mathrm{~N} \\
\text { Longitude- } \\
77^{*} 41^{\prime} 35 " \mathrm{E}\end{array}$ & Herb & Rhizome & $\begin{array}{l}\text { Throughout } \\
\text { year }\end{array}$ & Yes & 49 & $\begin{array}{l}\text { It is a very popular } \\
\text { spice as well as the } \\
\text { main ingredient in } \\
\text { many traditional } \\
\text { and folk medicines. }\end{array}$ & $\begin{array}{l}\text { Ginger is beneficial against } \\
\text { human respiratory viruses } \\
\text { like the human respiratory } \\
\text { syncytial virus. It is } \\
\text { reported that ginger blocks } \\
\text { viral attachment [9]. }\end{array}$ \\
\hline 4. & $\begin{array}{l}\text { Aloe vera Linn. } \\
\text { (Liliaceae) } \\
\text { Korphad }\end{array}$ & $\begin{array}{l}\text { Latitude- } \\
19 * 16 ' 15 " \mathrm{~N} \\
\text { Longitude- } \\
77^{*} 41^{\prime} 36 " \mathrm{E}\end{array}$ & Herb & Leaves & $\begin{array}{l}\text { Throughout } \\
\text { year }\end{array}$ & No & 39 & $\begin{array}{l}\text { Leaf's sap is used } \\
\text { for making juice. It } \\
\text { is used for drinking } \\
\text { purposes to } \\
\text { enhance immunity. }\end{array}$ & $\begin{array}{l}\text { Its potential antiviral } \\
\text { activity is also reported } \\
\text { against COVID-19, both } \\
\text { separately or in } \\
\text { combination with other } \\
\text { plant species [10]. }\end{array}$ \\
\hline 5. & $\begin{array}{l}\text { Azadirachta indica } \\
\text { A. Juss (Meliaceae) } \\
\text { Neem }\end{array}$ & $\begin{array}{l}\text { Latitude- } \\
19 * 16 ' 33 " \mathrm{~N} \\
\text { Longitude- } \\
77^{*} 41^{\prime} 24 " \mathrm{E}\end{array}$ & Tree & Leaves & $\begin{array}{l}\text { Throughout } \\
\text { year }\end{array}$ & No & 26 & $\begin{array}{l}\text { Leaves boiled with } \\
\text { water; decoction } \\
\text { obtained useful in } \\
\text { fever. }\end{array}$ & $\begin{array}{l}\text { Neem crude extract is } \\
\text { useful to treat normal and } \\
\text { malarial fever, which are } \\
\text { the common systems of } \\
\text { COVID-19, this medicinal } \\
\text { plant is highly } \\
\text { recommended for the } \\
\text { treatment of patients }\end{array}$ \\
\hline
\end{tabular}




\begin{tabular}{|c|c|c|c|c|c|c|c|c|c|}
\hline $\begin{array}{l}\text { S. } \\
\text { No. }\end{array}$ & $\begin{array}{l}\text { Scientific name of } \\
\text { plants, family, } \\
\text { and local name }\end{array}$ & $\begin{array}{l}\text { GPS } \\
\text { location }\end{array}$ & Habit & $\begin{array}{l}\text { Edible } \\
\text { part } \\
\text { used } \\
\end{array}$ & $\begin{array}{l}\text { Season of } \\
\text { availability }\end{array}$ & $\begin{array}{l}\text { Commerci } \\
\text { ally sold }\end{array}$ & $\begin{array}{l}\text { Frequency } \\
\text { index }\end{array}$ & $\begin{array}{l}\text { Method of } \\
\text { consumption }\end{array}$ & Medicinal properties \\
\hline 6. & $\begin{array}{l}\text { Tribulus terrestris } \\
\text { Linn. } \\
\text { (Zygophyllaceae) } \\
\text { Sarata }\end{array}$ & $\begin{array}{l}\text { Latitude- } \\
19 * 16 \text { ' } 26 " \mathrm{~N} \\
\text { Longitude- } \\
77^{*} 41 \text { '18"E }\end{array}$ & Herb & $\begin{array}{l}\text { Whole } \\
\text { plant }\end{array}$ & Rainy & No & 24 & $\begin{array}{l}\text { Leaves extract is } \\
\text { helpful to enhance } \\
\text { immunity. }\end{array}$ & $\begin{array}{l}\text { suffering from COVID-19 } \\
\text { [11]. } \\
\text { Major bioactive } \\
\text { compounds are six } \\
\text { cinnamic amides and } \\
\text { ferulic acid was showing } \\
\text { inhibition of Papain-like } \\
\text { protease (PLpro), which is } \\
\text { a major protein target of } \\
\text { COV-19 [12]. }\end{array}$ \\
\hline 7. & $\begin{array}{l}\text { Allium cepa Linn. } \\
\text { (Liliaceae) Kanda }\end{array}$ & $\begin{array}{l}\text { Latitude- } \\
19 * 16 ' 18 " \mathrm{~N} \\
\text { Longitude- } \\
77^{*} 41 \text { ' } 30 " \mathrm{E}\end{array}$ & Herb & Bulb & $\begin{array}{l}\text { Throughout } \\
\text { year }\end{array}$ & Yes & 49 & $\begin{array}{l}\text { It is used for flavour } \\
\text { and taste. }\end{array}$ & $\begin{array}{l}\text { Various studies concluded } \\
\text { that it has antiviral activity } \\
\text { against respiratory viruses } \\
\text { [13]. }\end{array}$ \\
\hline 8. & $\begin{array}{l}\text { Punica granatum } \\
\text { (Lythraceae) } \\
\text { Pomegranate }\end{array}$ & $\begin{array}{l}\text { Latitude- } \\
19 * 16 ' 20 " \mathrm{~N} \\
\text { Longitude- } \\
77 * 42 \text { '1"E }\end{array}$ & Shrub & Fruits & Winter & Yes & 36 & $\begin{array}{l}\text { Fruit juice of } \\
\text { pomegranate is } \\
\text { useful in clinical } \\
\text { conditions. }\end{array}$ & $\begin{array}{l}\text { Beneficial in anaemia, } \\
\text { colic, acute dermatitis, oral } \\
\text { diseases, acne, and many } \\
\text { others. Pomegranate also } \\
\text { has an observed effect to } \\
\text { reduce angiotensin- } \\
\text { converting enzymes [14]. }\end{array}$ \\
\hline 9. & $\begin{array}{l}\text { Momordica } \\
\text { charantia } \\
\text { (Cucurbitaceae) } \\
\text { Bitter Gourd/Karela }\end{array}$ & $\begin{array}{l}\text { Latitude- } \\
19 * 16 ' 26 " \mathrm{~N} \\
\text { Longitude- } \\
77^{*} 41 \text { '18"E }\end{array}$ & $\begin{array}{l}\text { Climb } \\
\text { er }\end{array}$ & Fruits & Winter & Yes & 28 & $\begin{array}{l}\text { Fruit juice is used to } \\
\text { cure viral infections. }\end{array}$ & $\begin{array}{l}\text { Its potent protein inhibits } \\
\text { many viruses like Dengue, } \\
\text { Herpes, hepatitis-B, and } \\
\text { HIV [15]. }\end{array}$ \\
\hline 10. & $\begin{array}{l}\text { Allium sativum } \\
\text { Linn. (Liliaceae) } \\
\text { Lahsun }\end{array}$ & $\begin{array}{l}\text { Latitude- } \\
19 * 16 \text { '18"N } \\
\text { Longitude- } \\
77^{*} 41 \text { ' } 31 " \mathrm{E}\end{array}$ & Herb & Bulb & $\begin{array}{l}\text { Throughout } \\
\text { year }\end{array}$ & Yes & 36 & $\begin{array}{l}\text { It is one of the } \\
\text { spices as well as the } \\
\text { main ingredient in } \\
\text { many traditional } \\
\text { and folk medicines. }\end{array}$ & $\begin{array}{l}\text { Its potent compound is } \\
\text { allicin active against } \\
\text { cardiovascular disease } \\
\text { [16]. }\end{array}$ \\
\hline 11. & $\begin{array}{l}\text { Tinospora } \\
\text { cordifolia Rich. } \\
\text { (Menispermaceae) } \\
\text { Gulvel }\end{array}$ & $\begin{array}{l}\text { Latitude- } \\
19 * 16 ' 20 " \mathrm{~N} \\
\text { Longitude- } \\
77 * 41 \text { '29"E }\end{array}$ & $\begin{array}{l}\text { Climb } \\
\text { er }\end{array}$ & $\begin{array}{l}\text { Stem and } \\
\text { Leaves }\end{array}$ & $\begin{array}{l}\text { Throughout } \\
\text { year }\end{array}$ & No & 32 & $\begin{array}{l}\text { Stem and fresh } \\
\text { leaves of the herb } \\
\text { are crushed and } \\
\text { boiled in water, so } \\
\text { decoction is } \\
\text { obtained used to } \\
\text { cure a cold and } \\
\text { cough. }\end{array}$ & $\begin{array}{l}\text { It is useful against viruses } \\
\text { by blocking fusion or } \\
\text { adsorption [17]. }\end{array}$ \\
\hline 12. & $\begin{array}{l}\text { Emblica officinalis } \\
\text { Gaertn., } \\
\text { (Phyllanthaceae) } \\
\text { Amla }\end{array}$ & $\begin{array}{l}\text { Latitude- } \\
19 * 13 \text { '34"N } \\
\text { Longitude- } \\
77^{*} 40 \text { ' } 20 " \mathrm{E}\end{array}$ & Tree & Fruits & Winter & Yes & 25 & $\begin{array}{l}\text { Fruits are the most } \\
\text { widely used in } \\
\text { medicine as a } \\
\text { diuretic, restorative, } \\
\text { liver tonic, and for } \\
\text { common cold and } \\
\text { fever. }\end{array}$ & $\begin{array}{l}\text { Pentagalloyl glucose, found } \\
\text { in the amla fruit can inhibit } \\
\text { replication of the } \\
\text { Influenza-A virus [18]. }\end{array}$ \\
\hline 13. & $\begin{array}{l}\text { Withania somnifera } \\
\text { Linn. (Solanaceae) } \\
\text { Ashwagandha }\end{array}$ & $\begin{array}{l}\text { Latitude- } \\
19 * 16 \text { ' } 21 " \mathrm{~N} \\
\text { Longitude- } \\
77^{*} 41 \text { ' } 34 " \mathrm{E}\end{array}$ & Shrub & Root & $\begin{array}{l}\text { Throughout } \\
\text { year }\end{array}$ & No & 29 & $\begin{array}{l}\text { In ayurvedic } \\
\text { preparations, it is } \\
\text { used as a general } \\
\text { tonic and to boost } \\
\text { immunity }\end{array}$ & $\begin{array}{l}\text { According to Grover [19], } \\
\text { Withaferin A inhibits the } \\
\text { DNA polymerase enzyme } \\
\text { of the virus which doesn't } \\
\text { allow viral replication. }\end{array}$ \\
\hline 14. & $\begin{array}{l}\text { Ocimum sanctum } \\
\text { Linn. (Lamiaceae) } \\
\text { Tulasi }\end{array}$ & $\begin{array}{l}\text { Latitude- } \\
19 * 16 ' 16 " \mathrm{~N} \\
\text { Longitude- } \\
77^{*} 41 \text { ' } 20 " \mathrm{E}\end{array}$ & Shrub & Leaves & $\begin{array}{l}\text { Throughout } \\
\text { year }\end{array}$ & No & 51 & $\begin{array}{l}\text { Fresh leaves boiled } \\
\text { with water, } \\
\text { decoction obtained } \\
\text { useful in cough and } \\
\text { cold. }\end{array}$ & $\begin{array}{l}\text { Being used for curing pain, } \\
\text { diarrhoea, cough, and } \\
\text { fever, which are common } \\
\text { symptoms related to } \\
\text { COVID-19 [20]. }\end{array}$ \\
\hline 15. & $\begin{array}{l}\text { Astragalus } \\
\text { membranaceus } \\
\text { (Fabaceae) } \\
\text { Astragalus }\end{array}$ & $\begin{array}{l}\text { Latitude- } \\
19 * 15 ' 15 " \mathrm{~N} \\
\text { Longitude- } \\
77^{*} 40 \text { ' } 28 " \mathrm{E}\end{array}$ & Shrub & Roots & Winter & No & 22 & $\begin{array}{l}\text { Root extract used to } \\
\text { enhance immunity. }\end{array}$ & $\begin{array}{l}\text { In an in vitro/in vivo study } \\
\text { published in } 2013 \text { on } \\
\text { H9N2 avian influenza } \\
\text { virus-infected chickens, } \\
\text { Astragalus polysaccharides } \\
\text { are reported to enhance } \\
\text { immunity and prohibit } \\
\text { viral infection [21]. }\end{array}$ \\
\hline 16. & $\begin{array}{l}\text { Syzygium } \\
\text { aromaticum Linn. } \\
\text { (Myrtaceae) } \\
\text { Clove/Laung }\end{array}$ & $\begin{array}{l}\text { Latitude- } \\
19 * 16 \text { '16"N } \\
\text { Longitude- } \\
77^{*} 41 \text { ' } 20 " \mathrm{E}\end{array}$ & Shrub & Flowers & Winter & Yes & 31 & $\begin{array}{l}\text { Flower calyx is used } \\
\text { as spice, flavour, } \\
\text { and taste. }\end{array}$ & $\begin{array}{l}\text { The eugeniin present in } \\
\text { clove has potent antiviral } \\
\text { activity [22]. }\end{array}$ \\
\hline 17. & $\begin{array}{l}\text { Piper betel } \\
\text { (Piperaceae) Betel } \\
\text { vine/Paan }\end{array}$ & $\begin{array}{l}\text { Latitude- } \\
19 * 16 \text { '18"N } \\
\text { Longitude- } \\
77^{*} 41 \text { ' } 31 " \mathrm{E}\end{array}$ & $\begin{array}{l}\text { Climb } \\
\text { er }\end{array}$ & Fruits & Winter & No & 18 & $\begin{array}{l}\text { Fruits are used for } \\
\text { chewing purposes, } \\
\text { as they were useful } \\
\text { on an aphrodisiac, } \\
\text { carminative, } \\
\text { laxative, and } \\
\text { improve appetite. }\end{array}$ & $\begin{array}{l}\text { Fruits in addition to honey } \\
\text { effective against cough } \\
\text { [23]. }\end{array}$ \\
\hline
\end{tabular}

\section{CONCLUSION}

The selected traditional herbal medicinal plants used in Indian traditional medicine offer an effective solution or may help in the discovery of new drug molecules. The extracts or formulations of these herbal medicinal plants work as a potential antiviral remedy. They also have phytochemicals and other metabolites that offer a plethora of immunity-boosting properties resulting in an improved 
immune system of the human body to fight against COVID-19. The leaves of Azadirachta indica, Aloe vera, and Ocimum sanctum are used to treat colds. The fruits of Momordica charantia, Emblica officinalis, and Piper betel are effective remedies for cough treatment. Rhizome of Curcuma longa Linn. and Zingiber officinale Roscoe beneficial against viral infections. Roots of Withania somnifera Linn. and Astragalus membranaceus are used to enhance the immune system. Stem and leaves decoction of Tinospora cordifolia is used to cure a cold and cough. Seed gravy prepared from Trigonella foenum-graecum Linn. is used for self-immune enhancement. Bulb of Allium cepa Linn. and Allium sativum Linn. has been used from ancient times in many traditional and folk medicines. A holistic approach with the above selected herbal medicinal plant formulations will help to build immunity. Further studies will help to explore the possibility of combined therapies with other naturally derived substances or standard therapeutics resulting in the development of broad-spectrum antidotes for the prevention and control of viral diseases like COVID-19. The study is primitive and based on an inadequate sample structure. The findings of the study are not directly implementable as a medical practice since it would amount to be an audacious step. Some of the plants found are rare and grow only in hilly and deep forest areas, thus marring its availability.

\section{ACKNOWLEDGEMENT}

The authors are thankful to UGC for providing the funding to one of the authors for the current research activity. Also, sincere thanks to tribal healers of the area under our study for sharing their traditional knowledge with us during the extensive field visits.

\section{AUTHORS CONTRIBUTIONS}

In this work, the Actual data collection and referencing have done by Mr. S. S. Shinde, Dr. SD Raut has contributed to the preparation of the manuscript all this has been done under the supervision of Dr. B. D. Gachande. All authors read and approved the final manuscript

\section{CONFLICT OF INTERESTS}

The authors declare no conflict of interest

\section{REFERENCES}

1. Gangal N, Nagle V, Pawar Y, Dasgupta S. Reconsidering traditional medicinal plants to combat COVID-19. AIJR Prepr. 2020 Apr 15;34:1-6.

2. Covid. Who. Int; 2022. WHO. Coronavirus (COVID-19) dashboard [online]. Available from: https://covid19.who.int. [Last accessed on 03 Jan 2022]

3. Mohfw.gov.in. 2022. MoHFW | Home. [online] Available from: <https://www.mohfw.gov.in/> [Last accessed on 03 Jan 2022]

4. Felsenstein S, Herbert JA, McNamara PS, Hedrich CM. COVID19: immunology and treatment options. Clin Immunol. 2020 Jun 1;215:108448. doi: 10.1016/j.clim.2020.108448.

5. Tabuti JR, Lye KA, Dhillion SS. Traditional herbal drugs of Bulamogi, Uganda: plants, use and administration. J Ethnopharmacol. 2003 Sep 1;88(1):19-44. doi: 10.1016/s03788741(03)00161-2, PMID 12902048.

6. Madikizela B, Ndhlala AR, Finnie JF, Van Staden J. Ethnopharmacological study of plants from pondoland used against diarrhoea. J Ethnopharmacol. 2012 May 7;141(1):6171. doi: 10.1016/j.jep.2012.01.053, PMID 22338648.

7. Chen DY, Shien JH, Tiley L, Chiou SS, Wang SY, Chang TJ, Lee YJ, Chan KW, Hsu WL. Curcumin inhibits influenza virus infection and haemagglutination activity. Food Chem. 2010 Apr 15;119(4):1346-51. doi: 10.1016/j.foodchem.2009.09.011.

8. Madhava Naidu M, Shyamala BN, Pura Naik J, Sulochanamma G, Srinivas P. Chemical composition and antioxidant activity of the husk and endosperm of fenugreek seeds. LWT Food Sci Technol. 2011 Mar 1;44(2):451-6. doi: 10.1016/j.lwt.2010.08.013.

9. Chang JS, Wang KC, Yeh CF, Shieh DE, Chiang LC. Fresh ginger (Zingiber officinale) has anti-viral activity against human respiratory syncytial virus in human respiratory tract cell lines. J Ethnopharmacol. 2013;145(1):146-51. doi: 10.1016/j.jep.2012.10.043. PMID 23123794.

10. Qazi AS, Akhtar N, Khan Khalil AA, Ahmed MS, Mumtaz S. A possible role of medicinal plants in finding a cure for covid-19. Life Sci. 2020 Dec 23;1Suppl:5. doi: 10.37185/LnS.1.1.156.

11. Roy S, Bhattacharyya P. Possible role of traditional medicinal plant Neem (Azadirachta indica) for the management of COVID19 infection. IJRPS. 2020;11(SPL1):122-5. doi: 10.26452/ijrps.v11iSPL1.2256.

12. Song YH, Kim DW, Curtis Long MJ, Yuk HJ, Wang Y, Zhuang N, Lee KH, Jeon KS, Park KH. Papain-like protease (PLpro) inhibitory effects of cinnamic amides from Tribulus terrestris fruits. Biol Pharm Bull. 2014 Jun 1;37(6):1021-8. doi: 10.1248/bpb.b14-00026, PMID 24882413.

13. Chiang LC, Chiang W, Liu MC, Lin CC. In vitro antiviral activities of caesalpinia pulcherrima and its related flavonoids. J Antimicrob Chemother. 2003 Aug 1;52(2):194-8. doi: 10.1093/jac/dkg291, PMID 12837746.

14. Santos RL, Lima JT, Rouver WN, Moyses MR. Deficiency of sex hormones does not affect 17-ßestradiol-induced coronary vasodilation in the isolated rat heart. Braz J Med Biol Res. 2016 Apr 12;49(5). doi: 10.1590/1414-431x20165058.

15. Waiyaput W, Payungporn S, Issara Amphorn J, Panjaworayan NT. Inhibitory effects of crude extracts from some edible Thai plants against replication of hepatitis B virus and human liver cancer cells. BMC Complement Altern Med. 2012 Dec;12(1):246. doi: 10.1186/1472-6882-12-246, PMID 23216691.

16. Chan JY, Yuen AC, Chan RY, Chan SW. A review of the cardiovascular benefits and antioxidant properties of allicin Phytother Res. 2013 May;27(5):637-46. doi: 10.1002/ptr.4796, PMID 22888009.

17. Choudhary N, Siddiqui MB, Azmat S, Khatoon S. Tinospora cordifolia: ethnobotany, phytopharmacology and phytochemistry aspects. Int J Pharm Sci Res. 2013 Mar 1;4(3):891.

18. Dasaroju S, Gottumukkala KM. Current trends in the research of Emblica officinalis (Amla): A pharmacological perspective. Int J Pharm Sci Rev Res. 2014;24(2):150-9.

19. Grover A, Agrawal V, Shandilya A, Bisaria VS, Sundar D. Nonnucleosidic inhibition of herpes simplex virus DNA polymerase: mechanistic insights into the anti-herpetic mode of action of herbal drug withaferin A. InBMC Bioinformatics. 2011 Dec.

20. Goothy SS, Goothy S, Choudhary A, Potey GG, Chakraborty H, Kumar AH, Mahadik VK. Ayurveda's holistic lifestyle approach for the management of coronavirus disease (COVID-19): possible role of tulsi. Int J Res Pharm Sci. 2020:16-8.

21. Kallon S, Li X, Ji J, Chen C, Xi Q, Chang S, Xue C, Ma J, Xie Q, Zhang Y. Astragalus polysaccharide enhances immunity and inhibits H9N2 avian influenza virus in vitro and in vivo. J Anim Sci Biotechnol. 2013 Dec;4(1):22. doi: 10.1186/2049-1891-4-22, PMID 23786718.

22. Lee KG, Shibamoto T. Antioxidant property of aroma extract isolated from clove buds [Syzygium aromaticum (L.) Merr. et Perry] [Syzygium aromaticum (L.) Merr. et Perry]. Food Chem. 2001 Sep 1;74(4):443-8. doi: 10.1016/S0308-8146(01)00161-3.

23. Aruljothi S, Uma C, Sivagurunathan P. Comparative evaluation on the antibacterial activity of karpoori variety piper betle leaves against certain Bacterial Pathogens. Int J Sci Res Methodol. 2016;3:35-45. 